\title{
BIOCOMPATIBILITY OF MESENCHYMAL STROMAL CELLS OF ADIPOSE TISSUE WITH OSTEOPLASTIC MATERIALS (IN VITRO)
}

\author{
Andrii BAMBULIAK ${ }^{1 凶}$ \\ ${ }^{1}$ Higher State Educational Establishment of Ukraine „Bukovinian State Medical University“, Chernivtsi, \\ Ukraine
}

\section{Abstract}

Introduction. The use of stem cells in dental practice has become possible due to the phenomenal discovery in biology and biotechnology regarding the ability of stem cells, after injecting them into the recipient's body, to enter the places of damaged tissues and restore their cellular structure. Since bone healing occurs by replacing a defect with connective tissue, our task was to transplant multipotent stem cells, which will later differentiate into the actual bone tissue.

The aim of the study was to determine the biocompatibility of mesenchymal stromal cells of adipose tissue (MMSC - AT) with osteoplastic materials.

Material and methods. The research was conducted within the Bukovinian State Medical University, Chernivtsi, Ukraine, from May 2018 to February 2019. Samples of adipose tissue were obtained from the neck area of 60 experimental animals (white Wistar line rats). We conducted an analysis of phenotypic markers multipotent mesenchymal stromal cells of adipose tissue. It was determined the degree of remineralization of these samples, which was confirmed by Alamar Blue test (AB).

Results. Analysis of the degree of mineralization of the extracellular matrix revealed that the investigated

\section{Résumé}

Biocompatibilité des cellules stromales mésenchymateuses du tissu adipeux avec des matériaux ostéoplastiques.

Introduction. L'utilisation de cellules souches en pratique dentaire est devenue possible grâce aux découvertes phénoménales en biologie et en biotechnologie, qui ont trait à la capacité des cellules souches après leur introduction dans le corps receveur de pénétrer les sites des tissus lésés et de restaurer leur structure cellulaire. Étant donné que la guérison du tissu osseux consiste à remplacer le défaut par le tissu conjonctif, notre tâche consistait à transplanter des cellules souches multipotentes, qui se différencient à l'avenir du tissu osseux.

Le but de l'étude était de déterminer la biocompatibilité des cellules stromales mésenchymateuses du tissu adipeux à l'aide de matériaux ostéoplastiques. Méthodes. La recherche a été menée sur la base de l'Université de médecine d'État de Bucovine, à Tchernivtsi, en Ukraine, de mai 2018 à février 2019. Des échantillons de tissu adipeux ont été prélevés dans la région du cou de 60 animaux de laboratoire (rats de 
samples with the contents of multipotent mesenchymal stromal cells of adipose tissue (MMSC-AT) had osteogenic potential, which was more pronounced in the samples of MMSC-AT + platelet-rich plasma (PRP) and MMSC-AT + PRP + Kolapan. The cultured MMSC-AT tissues from experimental rats of the $2^{\text {nd }}$ passage express the markers characteristic of MMSC, MMSC-AT capable of differentiation in the osteogenic direction, with the prevalence of this process in tissue samples containing Platelet-Enriched Plasma and Kolapan.

Conclusions. Consequently, the tissue equivalent of bone tissue based on MMSC-AT can be used in regenerative medicine, and also can be used in different directions of dentistry.

Keywords: mesenchymal stromal cells, adipose tissue, plateletrich plasma, collagen.

\section{List of abbreviations:}

MMSC= multipotent mesenchymal stromal cells MMSC-AT= multipotent mesenchymal stromal cells of adipose tissue

$\mathrm{PRP}=$ platelet-rich plasma

$\mathrm{AB}=$ Alamar Blue test

$\mathrm{CU}=$ conventional units

$\mathrm{CUF}=$ conventional units of fluorescence

\section{INTRODUCTION}

In medical practice, specialists quite often encounter injuries of various aetiologies. The current goal is to make reconstruction of the damaged tissue in a short term, with minimal cost and effect on the organism. The use of stem cells in dental practice has become possible due to the phenomenal discovery in biology and biotechnology regarding the ability of stem cells, after injecting them into the recipient's body, to enter the places of damaged tissues and restore their cellular structure ${ }^{1-3}$.

The ability of stem cells to differentiate into almost all specialized cells of the body and perform specific biological functions has been established. Researchers work mainly with embryonic and mesenchymal stem cells ${ }^{4,5}$. Mesenchymal stem cells are found in the stroma of the bone marrow, which is one of the varieties of adult stem cells ${ }^{6,7}$. In particular, they were isolated from skeletal muscle, adipose tissue, lungs, fetal liver, cord blood ${ }^{8-10}$. They are referred to multipotent cells, that is, capable of differentiating into connective tissue cells, including bone, adipose, cartilage and muscle tissues, therefore they are optimal for cell regenerative therapy of injuries to the above-mentioned tissues ${ }^{11-13}$. la lignée Wistar blanche). Nous avons effectué une analyse des marqueurs phénotypiques des cellules stromales mésenchymateuses multipotentes du tissu adipeux. Le degré de reminéralisation de ces échantillons a été déterminé, ce qui a été confirmé par le test Alamar Blue.

Les résultats. L'analyse du degré de minéralisation de la matrice extracellulaire a révélé que le contenu en MMSC-AT avait un potentiel ostéogène, qui était plus prononcé dans les échantillons de MMSC-AT + PRP et de MMSC-AT + PRP + Kolapan. Les tissus MMSC-AT cultivés du 2e passage expriment les marqueurs caractéristiques du MMSC, le MMSC-AT capable de différenciation dans le sens ostéogénique, avec la prévalence de ce processus dans des échantillons de tissu contenant du plasma enrichi en plaquettes et du Kolapan.

Conclusions. Par conséquent, l'équivalent tissulaire de tissu osseux basé sur le MMSC-AT peut être utilisé en médecine régénérative et peut également avoir une application clinique dans différentes directions de la dentisterie.

Mots-clés: cellules stromales mésenchymateuses, tissu adipeux, plasma riche en plaquettes, collagène.

The optimal source of multipotent stem cells is fatty tissue ${ }^{14,15}$. First of all, this is due to the availability of the method of obtaining cells, low invasiveness for the body, the ability to obtain cellular material in sufficient quantity and at the right time. Multipotent mesenchymal stromal cells (MMSC) from adipose tissue are capable of differentiation in adipogenic, osteogenic, chondrogenic, endothelial, myogenic, hepatogenic, epithelial and neurogenic directions ${ }^{16-18}$.

Since bone healing occurs by replacing a defect with connective tissue, our task was to transplant multipotent stem cells, which will later differentiate into the actual bone tissue ${ }^{19,20}$.

The OBJECTIVE OF THE STUDY was to determine the biocompatibility of mesenchymal stromal cells of adipose tissue with osteoplastic materials.

\section{Materials AND MEthods}

The research was conducted on the basis of Bukovinian State Medical University, Chernivtsi, Ukraine, from May 2018 to February 2019. Samples of adipose tissue were obtained from the neck area of 60 experimental animals (white Wistar line rats). For the toxicological experiment, which allows to 


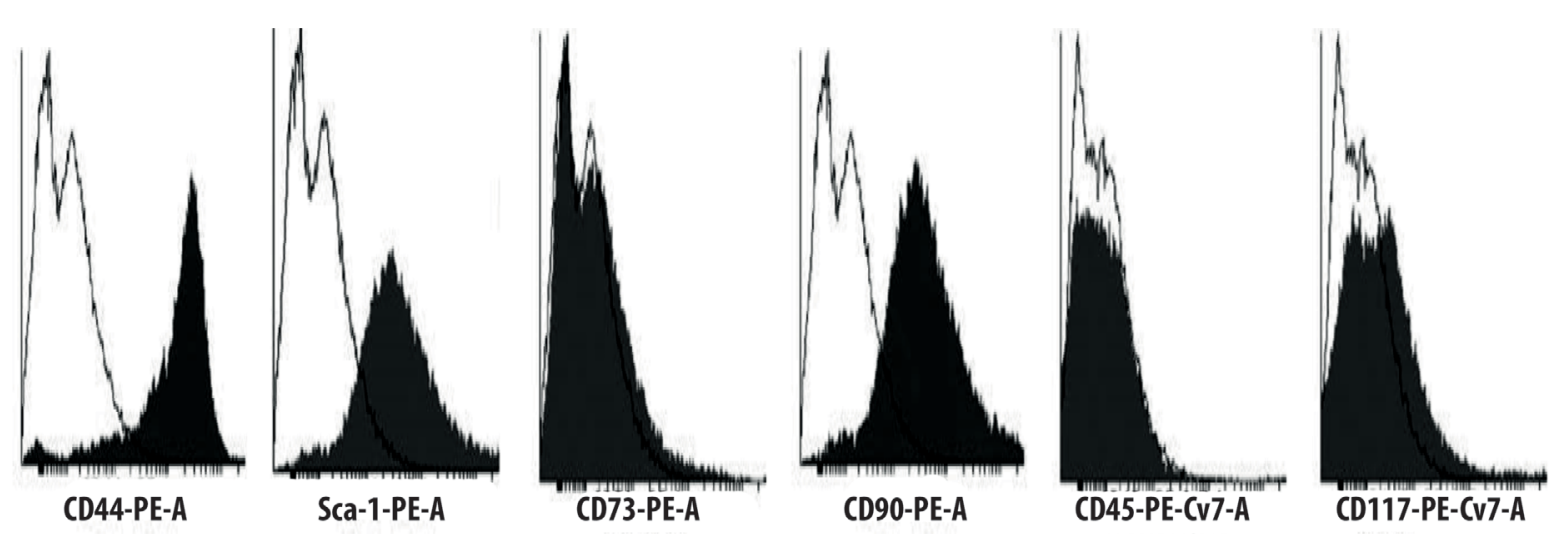

Fig. 1. Histogram of expression of surface markers CD 44, Sca-1, CD 73, CD 90, CD 45, CD 117 in rat adipose tissue cell cultures. Transparent histogram of control samples without the introduction of antibodies, dark - the level of fluorescence in the sample with the addition of monoclonal antibodies

establish the direct influence of factors on contact of the implant material at the cellular level, 4 samples were selected: $\mathrm{N}^{\circ} 1$ - MMSC-AT, which underwent osteogenic differentiation; $\mathrm{N}^{\circ} 2$ - multipotent mesenchymal stromal cells of adipose tissue (MMSC-AT) with osteogenic differentiation with the addition of platelet-rich plasma; No№ 3 - „Kolapan“ with applied tissue culture MMSC-AT, which underwent osteogenic differentiation; No 4 - „Kolapan“ with applied tissue culture of MMSC-AT which underwent osteogenic differentiation and platelet-rich blood plasma.

Multipotent mesenchymal cells of adipose tissue (MMSC-AT) were obtained by grinding the adipose tissue of rats in $0.1 \%$ collagenase $1 \mathrm{~A}^{21}$. Phenotyping of MMSC-AT on markers of DM 44, DM 45, DM 73, DM 90, DM 117, Sca-1 was performed using monoclonal antibodies to mouse membrane antigens conjugated with fluorochromes at a working concentration of $0.5 \mu \mathrm{g} / \mathrm{mL}$ (Becton Dickinson, USA). As control, samples of cells were used without antibodies (unstable control). At the same time, the level of fluorescence in the samples was determined by the addition of each of the monoclonal antibodies separately (single staining sample). Measurements were carried out on a laser flow cytometric sorter, BD FACS Diva 6.1. Histogram overlays were performed using Cyflogic v. 1.2.122.24. For directed osteogenic differentiation, MMSC-AT cells were placed in $90 \mathrm{~mm}$ Petri cup or 6-well plates, and after the cells reached a confluent monolayer, they were replaced with a differentiated nutrient medium (nutrient medium with the addition of 1.25 - dihydroxyvitamin D3 10 $8 \mathrm{M}$, L-ascorbic acid $50 \mathrm{mg} / \mathrm{L}, \beta$-glycerophosphate (Sigma). To determine the foci of mineralization, the cells were washed twice with phosphate buffer (LanEco, Russia), fixed with cooled $70 \%$ ethanol, and stained with $40 \mathrm{mM}$ alizarin red $\mathrm{S}(\mathrm{ph}=4.1)$
(Mosreaktiv, Russia) for 5 minutes. The unrelated dye was washed with phosphate-salt buffer ${ }^{25,26}$. The evaluation of fibroblast proliferation was performed using the Alamar Blue (AB, Serotec) test at 3, 7 and 10 days after the start of the experiment. For this, after 24 hours of cultivation, the cells were colonized with cells that were transferred into the wells of a 24-well plate with culture medium containing 10\% Alamar Blue (AB), incubation was carried out for 2 hours at $37^{\circ} \mathrm{C}^{27}$. Then, a medium was taken, in which the level of $\mathrm{AB}$ reduction was determined using a Tecan Spectrofluorometer (GENios, Austria) at $550 \mathrm{~nm}$ and an emission of $590 \mathrm{~nm}$. The data were presented as the difference between experimental and idle samples (without cells) and expressed in the conventional units of fluorescence (CUF) ${ }^{28}$.

\section{Results}

Phenotypic analysis of MMSC-AT revealed a profile of surface markers expression that are characteristics of stromal cells with multipotent properties (Fig. 1).

In the study of 0-passage samples (3-4 days of observation), it was determined expression of surface antigens of CD 73 to $73.5 \pm 6.68 \%$ of cells affecting T- and B-lymphocyte populations and CD 45 to 60.5 $\pm 5.50 \%$ of the cells responsible for the presence of hematopoietic cells. At the same time, when studying samples of 0 -passage, a high number of CD 117 helper cells $(95.0 \pm 8.64 \%)$ were observed, initiating stem cell growth factor.

Phenotypic analysis of second passage markers MMSC-AT showed expression of Sca-1 antigens up to $89.3 \pm 8.12 \%$, CD 90 - up to $93.7 \pm 8.52 \%$, CD 44 - up to $97.8 \pm 8,98 \%$ that 2.7, 9.4 and 4.0 times, respectively, exceeded the quantitative composition 
Table 1. Phenotypic analysis of surface markers of MMSC-AT in the rats of the Wistar line, $M \pm m, \%$

\begin{tabular}{ccccccc}
\hline Samples & $\begin{array}{c}\text { Sca-1, } \\
\%\end{array}$ & $\begin{array}{c}\text { CD 73, } \\
\%\end{array}$ & CD 117, & $\begin{array}{c}\text { CD 44, } \\
\%\end{array}$ & $\begin{array}{c}\text { CD 45, } \\
\%\end{array}$ & $\begin{array}{c}\text { CD 90, } \\
\%\end{array}$ \\
\hline O-passage & $32.9 \pm$ & $73.5 \pm$ & $95.0 \pm$ & $23.8 \pm$ & $60.5 \pm$ & $10.0 \pm$ \\
MMSC-AT & \pm 2.99 & \pm 6.68 & \pm 8.64 & \pm 2.53 & \pm 5.50 & \pm 0.91 \\
\hline 2-passage & $89.3 \pm$ & $14.5 \pm$ & $4.7 \pm$ & $97.8 \pm$ & $1.60 \pm$ & $93.7 \pm$ \\
MMSC-AT & $\pm 8.12^{\circ}$ & $\pm 1.32^{\circ}$ & $\pm 0.43^{\circ}$ & $\pm 8.98^{\circ}$ & $\pm 0.15^{\circ}$ & $\pm 8.52^{\circ}$ \\
\hline Note. ${ }^{\circ}$ p $<0.01$ - reliable difference regarding the data values 0-passage MMSC-AT.
\end{tabular}

Table 2. The degree of mineralization of crops MMSC-AT by the colometric method

\begin{tabular}{|c|c|c|c|}
\hline \multirow{2}{*}{ Samples } & \multicolumn{3}{|c|}{ Terms of observation } \\
\hline & $5^{\text {th }} d a y$ & $7^{\text {th }}$ day & $10^{\text {th }}$ day \\
\hline $\begin{array}{c}\mathrm{N}^{\circ} 1 \\
(\mathrm{MMSC}-\mathrm{AT}) \\
\end{array}$ & $1.38 \pm 0.27$ & $2.56 \pm 0.51$ & $2.95 \pm 0.59$ \\
\hline $\begin{array}{c}\text { No } 2 \\
\text { (MMSC-AT + PRP) }\end{array}$ & $3.15 \pm 0.43^{\circ \circ}$ & $3.92 \pm 0.74$ & $4.00 \pm 0.80$ \\
\hline $\begin{array}{c}\mathrm{N}^{\circ} 3 \\
\text { (MMSC-AT }+{ }_{\text {,Kolapan“) }}\end{array}$ & $2.64 \pm 0.32^{\circ \circ}$ & $2.76 \pm 0.55$ & $3.22 \pm 0.65$ \\
\hline $\begin{array}{c}\mathrm{N}^{\circ} 4 \\
(\text { MMSC-AT + PRP + „Kolapan“) }\end{array}$ & $3.86 \pm 0.56^{\circ \circ}$ & $4.85 \pm 0.97^{\circ}$ & $5.07 \pm 1.01^{\circ}$ \\
\hline
\end{tabular}

of surface antigens of the 0-passage MMSC-AT, p $<0.01$. At the same time, a decrease in pan leukocyte marker CD 45 - to $1.60 \pm 0.15 \%$ of cells, CD 117 - to $4.7 \pm 0.43 \%$, indicating the absence of hematopoietic cells in the studied samples (Table 1). Consequently, the same immunophenotypic profile was investigated by a number of authors for MMSC isolated from adipose tissue $\mathrm{e}^{29-31}$.

One of the main characteristics of MMSC-AT is the ability to differentiate into different types of connective tissue cells. In our study, to determine the biological properties of MMSC-AT, the potential of these cells to directed differentiation in the osteogenic direction was determined (Table 2).

The first signs of the influence of osteoinduction in the samples containing MMSC-AT appeared on day 7 of cultivation, regardless of their composition. At the same time, the studied samples acquired the phenotype of bone tissue, characterized by the formation of cultures with the formation of cell aggregates, the synthesis of a dense extracellular matrix with calcification phenomena.

It was found that on the 5th day of cultivation, a small optical density was in samples No. 1 and No. $3-1.38 \pm 0.27$ conventional units and $2.64 \pm 0.32$ conventional units, respectively, $p<0.01$. At the same time, the optical density of sample No. 3 was 2.3 times and sample No. 4 was 2.8 times greater than in the MMSC-AT culture (sample No. 1), p <0.01.

On day 7 of observations, an increase in the optical density of all tissue cultures studied was recorded. Attention was drawn to the fact that on the $7^{\text {th }}$ day of cultivation the value of the studied parameter was the same from sample number 1 and sample number 3 and varied from $2.56 \pm 0.51$ c.u., to $2.86 \pm 0.55$ c.u., $p>0.05$. At the same time, the optical density of the tissue culture containing MMSC-AT + Platelet-Rich Plasma (PRP) was 1.5 times, p> 0.05 and with MMSC-AT + PRP + Kolapan 1.9 times higher, $p$ $<0.05$ than the MMSC-AT sample.

On the $10^{\text {th }}$ day of observation, the optical density of sample No. 1 was $2.95 \pm 0.59$ c.u. and was minimal. The value of the parameter studied in tissue cultures "MMSC-AT + PRP» and "MMSC-AT + Kolapan» although they were 1.4 times and 1.1 times higher, respectively, but did not differ in statistical significance from the data of optical density of sample No. 1, p> 0.05 .

The nature of the effect of the studied samples containing MMSC-AT was confirmed by the results obtained using the Alamar Blue test in determining the metabolic activity of MMSC-AT in various samples (Table 3).

As a result of the studies, it was found that on day 5, the maximum reduction value of Alamar Blue (AB) was investigated in a control sample containing MMSC-AT with fluorescence data of $9.224 \pm 1623$ conditional units of fluorescence (c.u.f). At the same time, the minimum data of the fluorescence index on day 5 of cultivation was determined in sample No. 3 containing MMSC-AT + «Kolapan» - 7.126 \pm 1325 c.u.f, p> 0.05. In samples No. 2 (MMSC-AT + PRP) 
Table 3. Alamar Blue recovery rate in samples containing MMSC-AT at different observation time

\begin{tabular}{|c|c|c|c|c|}
\hline \multirow[b]{2}{*}{ Terms of observation } & \multicolumn{4}{|c|}{ Samples containing MMSC-AT } \\
\hline & $\begin{array}{l}\text { MMSC-AT (control) } \\
\text { Sample } \mathrm{N}^{\circ} 1\end{array}$ & $\begin{array}{c}\text { MMSC-AT + PRP } \\
\text { Sample } \mathrm{N}^{\circ} 2\end{array}$ & $\begin{array}{l}\text { MMSC-AT + „Kolapan“ } \\
\text { Sample N No } 3\end{array}$ & $\begin{array}{c}\text { MMSC-AT + PRP + } \\
\text { "Kolapan“" } \\
\text { Sample N } \mathrm{N}^{\circ} 4\end{array}$ \\
\hline $5^{\text {th }}$ day & $9.224 \pm 1623$ & $8.324 \pm 1.442$ & $7.126 \pm 1.325$ & $8624 \pm 1503$ \\
\hline $7^{\text {th }}$ day & $12449 \pm 1638$ & $9549 \pm 1457$ & $7351 \pm 1340^{\circ}$ & $10849 \pm 1518$ \\
\hline $10^{\text {th }}$ day & $19685 \pm 1653^{*}$ & $12785 \pm 1472^{\circ 0 * *}$ & $10587 \pm 1355^{\circ \circ}$ & $18085 \pm 1533^{*}$ \\
\hline $\begin{array}{l}\text { 1. }{ }^{\circ} \mathrm{p}<0.05 ;{ }^{\circ} \mathrm{p}<0.01 \\
\text { 2. }{ }^{*} \mathrm{p}_{1}<0.01 ;{ }^{* *} \mathrm{p}_{1}<0.0\end{array}$ & $\begin{array}{l}\text { reliable difference } \\
\text { reliable value diffe }\end{array}$ & $\begin{array}{l}\text { Notes: } \\
\text { or the data sample } \\
\text { ith respect to data }\end{array}$ & $\begin{array}{l}\text { ber } 1 . \\
\text { th days of cultivation. }\end{array}$ & \\
\hline
\end{tabular}

and No. 4 (MMSC-AT + PRP + «Kolapan»), the fluorescence index was $9.76 \%$ and $6.50 \%$ lower, respectively, for data sample No. 1, p > 0.05 .

On the $7^{\text {th }}$ day of cultivation, an increase in the values of AV recovery in all studied samples was determined. At the same time, the data of the fluorescence index in the control sample No. 1 were the maximum and exceeded the values: in the sample number 2 - by $23.30 \%$, in the sample number 3 - by $40.96 \%$ and in the sample number 4 - by $12.86 \%, p>0.05$.

On the $10^{\text {th }}$ day of the study, Alamar Blue recovery was maximal in all studied samples, with the highest value in the control sample No. $1-19685 \pm 1653$ c.u.f. At the same time, the value of the fluorescence index was lower than the data in the control: in the sample number 2 - by $35.05 \%$, in the sample number 3 - by $46.22 \%, p<0.01$ and in sample number 4 - by $3,05 \%, p>0.05$.

It was noted that the most recovery of Alamar Blue on the 10th day of cultivation was determined in samples No. 1, contained MMSC-AT and samples No. 4 (MMSC-AT + PRP + Kolapan), which was 2.13 times and 2, 09 times, $\mathrm{p} 1<0.01$ more than the corresponding values on the 5th day of cultivation. Slightly lower was the process of $A B$ recovery on the $10^{\text {th }}$ day of cultivation in samples No. 2 and in samples No. 3: 1.5 times, $\mathrm{p} 1<0.05, \mathrm{p} 1>0.05$, respectively.

Therefore, it should be noted that sample No. 4 is a more efficient carrier of MMSC-AT, due to the inclusion of platelet-rich plasma and Kolapan, and the presence of a broad-spectrum collagen structure that emphasizes the proliferation of cells within the carrier.

\section{Discussion}

Thus, cultured MMSC-AT tissues of experimental rats of the $2^{\text {nd }}$ passage express the markers characteristic of MMSC, MMSC-AT capable of differentiation in the osteogenic direction, with the prevalence of this process in tissue samples containing Platelet-Enriched Plasma and Kolapan. During osteogenic differentiation there was a morphological change of cells, with the synthesis, and mineralization of the extracellular matrix and the formation of cellular aggregates. Analysis of the degree of mineralization of the extracellular matrix revealed that the investigated samples with the contents of MMSC-AT had osteogenic potential, which was more pronounced in the samples of "MMSC-AT + PRP“ and „MMSC-AT + PRP +“ Kolapan „.

\section{Conclusions}

Consequently, the tissue equivalent of bone tissue based on MMSC-AT can be candidates for use in regenerative medicine, and the study of their use in experimental animals will provide an opportunity for expanding the understanding of the characteristics of MMSC-AT in order to optimize their subsequent clinical application and the implementation of new approaches in different directions of dentistry.

\section{Compliance with Ethics Requirements:}

„The authors declare no conflict of interest regarding this article"

„The authors declare that all the procedures and experiments of this study respect the ethical standards in the Helsinki Declaration of 1975, as revised in 2008(5), as well as the national law."

\section{References}

1. Gomillion CT, Burg KJ. Stem cells and adipose tissue engineering. Biomaterials. 2013;27 (36):6052-63.

2. Fu BC, Gao JH, Lu F, Li J. Experimental study of the effect of adipose stromal vascular fraction cells on the survival rate of fat transplantation Zhonghua Zheng Xing Wai Ke Za Zhi. 2016; 31 (3):289-294.

3. Ge W, Jiang J, Baroja ML, et al. Infusion of mesenchymal stem cells and rapamycin synergize to attenuate alloimmune responses and promote cardiac allograft tolerance Am J Transplant. 2014;4(3):1760-72. 
4. Mazurkevych AI, Kharkevych Yu O, Maliuk MO, Danilov VB, Kovpak VV, Zhurba VI. Influence of mesenchymal stem cells of bone marrow and embryonic fibroblasts of rats on the course of reparative processes in their skin. Scientific bulletin of the National University of Biological Resources and Prorodokoristuvannya of Ukraine. 2017;151(1):197-205.

5. Coleman SR, Mazzola RF, Pu Lee LQ. Fat injection: from filling to regeneration. 2nd ed. New York: CRC Press; 2016. $900 \mathrm{p}$.

6. Mazurkevych AI, Maliuk MO, Tkachenko SM, Kharkevych Yu O. Study of biocompatibility of haemostatic sponges with the barrel cages of marrow of rabbit during cultivation of in vitro. Bulletin of the Sumy National Agrarian University. 2015; 1(34):7-11.

7. Mazurkevych AI, Maliuk MO, Danilov VB. Methodical recommendations Use of mesenchymal stem cells for the correction of reparative processes in the organism of animals-recipients. Kyiv: MIO; 2014. 157 p.

8. Aggarwal S, Pittenger MF. Human mesenchymal stem cells modulate allogeneic immune cell responses. Blood. 2005;105:1815-22.

9. Augello A, Tasso R, Negrini SM. Bone marrow mesenchymal progenitor cells inhibit lymphocyte proliferation by activation of the programmed death 1 pathway. Eur J Immunol. 2013; 43:1482-90.

10. Mangashetti LS. IL-4 inhibits bone-resorbing activity of mature osteoclasts by affecting NF-kappa B and $\mathrm{Ca} 2+$ signaling. J Immunol. 2011;175:917-925.

11. Niemeyer P, Krause U, Kasten P. HLA-independent cell therapy for tissue engineering of bone and cartilage. Current Stem Cell Research and Therapy. 2012; 1 (1):21-7.

12. Quarto R, Mastrogiacomo M, Cancedda, et al. Repair of large bone defects with the use of autologous bone marrow stromal cells. N Engl J Med. 2011;344(5):385-6.

13. Roodman GD. Role of cytokines in the regulation of bone resorption. Calcif Tissue Int. 2013;1(61): 94-8.

14. Pittenger MF, Mackay AM, Beck SC, et al. Multilineage potential of adult human mesenchymal stem cells. Science. 2011;284:143-7.

15. Gimble J, Guilak F. Adipose-derived adult stem cells: isolation, characterization, and differentiation potential. Cytotherapy. 2013;5:362-9.

16. Yamanaka S. Pluripotency and nuclear reprogramming. Philosophical Transactions of the Royal Society of London. Series B: Biological Sciences. 2011; 363:2079-87.

17. Amabile G, Meissner A. Induced pluripotent stem cells: current progress and potential for regenerative medicine. Trends in Molecular Medicine. 2014;15:59-68.

18. Friedenstein AJ, Petrakova KV, Kurolesova AI, et al. Heterotopic of bone marrow. Analysis of precursor cells for osteogenic and hematopoietic tissues. Transplantation. 2014;6: 230-247

19. Jaiswal RK, Jaiswal N, Bruder SP, et al. Adult human mesenchymal stem cell differentiation to the osteogenic or adipogenic lineage is regulated by mitogen-activated protein kinase. The Journal of Biological Chemistry. 2016;275:9645-52.

20. Zuk PA. Tissue engineering craniofacial defects with adult stem cells? Are we ready yet? Pediatric Research. 2008;63:47886.

21. Johnstone B, Hering TM, Caplan AI, et al. In vitro chondrogenesis of bone marrow-derived mesenchymal progenitor cells. Experimental Cell Research. 2015; 238:265-72.

22. Zuk PA, Zhu M, Ashjian P, et al. Human adipose tissue is a source of multipotent stem cells. Molecular Biology of the Cell. 2012;13:4279-95.

23. Gimble JM, Katz AJ, Bunnell BA. Adipose-derived stem cells for regenerative medicine. Circulation Research. 2017;100:1249-60.

24. Planat-Benard V, Silvestre JS, Cousin B, et al. Plasticity of human adipose lineage cells toward endothelial cells: physiological and therapeutic perspectives. Circulation. 2010;109:656-63.

25. Seo MJ, Suh SY, Bae YC, et al. Differentiation of human adipose stromal cells into hepatic lineage in vitro and in vivo. Biochemical and Biophysical Research Communications. 2005;328: 258-64

26. Timper K, Seboek D, Eberhardt M, et al. Human adipose tissue-derived mesenchymal stem cells differentiate into insulin, somatostatin, and glucagon expressing cells. Biochemical and Biophysical Research Communications. 2013; 341:1135-40.

27. Winter A, Breit S, Parsch D, et al. Cartilage-like gene expression in differentiated human stem cell spheroids: a comparison of bone marrow-derived and adipose tissue-derived stromal cells. Arthritis and Rheumatism. 2016;48: 418-29.

28. Gonzalez-Rey E, Gonzalez MA, Varela N, et al. Human adipose-derived mesenchymal stem cells reduce inflammatory and $T$ cell responses and induce regulatory $T$ cells in vitro in rheumatoid arthritis. Annals of the Rheumatic Diseases. 2010; 69:241-8.

29. Gonzalez-Rey E, Anderson P, Gonzalez MA, et al. Human adult stem cells derived from adipose tissue protect against experimental colitis and sepsis. Gut. 2009; 58:929-39.

30. Meza-Zepeda LA, Noer A, Dahl JA, et al. High-resolution analysis of genetic stability of human adipose tissue stem cells cultured to senescence. Journal of Cellular and Molecular Medicine. 2013;12; 553-63.

31. Dahl JA, Duggal S, Coulston N, et al. Genetic and epigenetic instability of human bone marrow mesenchymal stem cells expanded in autologous serum or fetal bovine serum. The International Journal of Developmental Biology. 2008 $52 ; 1033-42$. 